\title{
IMPLEMENTATION OF DIGITAL LITERACY MOVEMENT FOR MSMES ACTORS IN JAKARTA THROUGH PARTICIPATORY ACTION RESEARCH
}

\author{
Rialdo Rezeky Manogari L. Toruan* \\ Departemen of Communication \\ Universitas Prof. Dr. Moestopo (Beragama) \\ Radja Erland Hamzah \\ Departemen of Communication \\ Universitas Prof. Dr. Moestopo (Beragama) \\ Muhammad Saifulloh \\ Departemen of Communication \\ Universitas Prof. Dr. Moestopo (Beragama) \\ *Correspondence: rialdorezeky@dsn.moestopo.ac.id
}

\section{ARTICLE INFO}

\section{Article History:}

received: $19 / 09 / 2021$

revised: $20 / 10 / 2021$

accepted: $31 / 10 / 2021$

\section{Keywords:}

Digital literacy, MSMEs, Participatory

Action Research, Online business

DOI:

https://doi.org/10.32509/mirshus.v1i2.22

\section{ABSTRACT}

Digital literacy is currently an interesting study in the midst of the development of Information and Communication Technology (ICT), especially for Micro, Small and Medium Enterprises (MSMEs). Through socialization and training, MSME actors can apply digital literacy in their business so that they become proficient, have the ability to market their products, and are able to increase income and improve the economy. This study aims to identify the actions of MSME actors in West Kuningan, South Jakarta (South Jakarta). The research approach used is qualitative with the Participatory Action Research (PAR) method and the digital literacy concept stage by Steve Wheeler. The research was conducted for three months, September to December 2020. The results showed that digital literacy can be implemented through socialization and training that is realized in a digital product. Through participatory action, MSME actors can be digitally literate and make good use of digital media, where they are able to create a marketing place in the form of a website (www.plazakuninganbarat.com) that can be used for online business. 


\section{INTRODUCTION}

This pandemic era that has been running for the last 1.5 years has provided more space for Information and Communication Technology (ICT) to advance, especially when the government urges people to do activities from home to prevent the spreading of coronavirus. The Central Statistics Agency recorded that throughout the 2020 pandemic, there is an increase in the internet use for various purposes up to 442 percent.

The figure is contributed by the widespread use of the internet for ordering goods from e-commerce and employees who work from home (wfh). In addition, based on data from the Ministry of Education, Culture, Research and Technology, there are $68,729,037$ students conducting distance learning (PJJ). Generally, users access the internet network from devices such as cell phones and laptops. They are part of 196.7 million internet users according to data from the Indonesian Internet Service Providers Association (Asosiasi Penyelenggara Jasa Internet Indonesia, 2020).

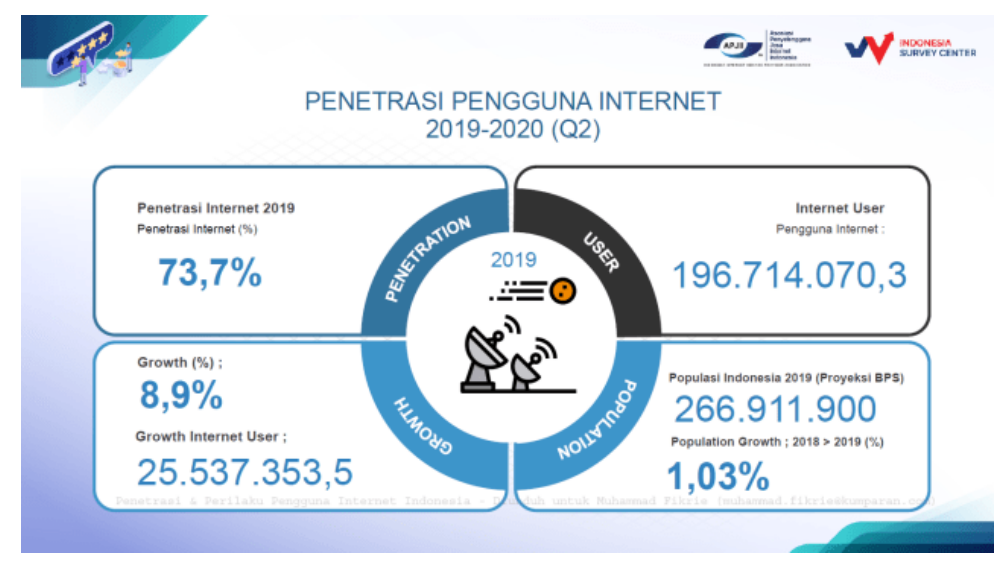

Figure 1

Total of Internet Users in Indonesia

(Source: APJII 2020, Quarter 2)

The above data shows that ICT is the only sector that experienced growth in three quarters throughout 2020. Cumulatively in 2020, the information and communication sector grew by 10.58 percent. This means that this sector has an extraordinary opportunity to be optimized by all Indonesian people.

Equitable digital literacy plays an important role in creating skilled human resources in using the internet so that they can encourage productivity and innovation in various sectors, especially in digital economy sector. The Bain Analysis study reports that the value of digital economy in Indonesia in 2020 grew 11 percent than that of 2019. In 2025, this value is estimated to be 124 billion US dollars. The Ministry of
Communication and Information believes that through digital literacy, the number of digitally onboarded MSMEs will continue to increase from the current figure, which is 12 million MSMEs.

Digital economy sector has great potential to become the main economic driving factor for Indonesia during pandemic. Data from BPS states that there is a year-on-year growth of around 10.58 percent in the information and communication sector which is directly related to digital economy sector. Furthermore, digital economy valuation in 2025 is predicted to reach IDR 1,700 trillion. There are three active components in digital economy, namely internet, artificial 
intelligence (AI), and e-commerce platforms (Permadi, 2021).

Micro, Small and Medium Enterprises (MSMEs) are one of the sectors in the Indonesian economy that have a crucial role. MSMEs have enormous potential in driving economic activity since they can become the main sources of income for most people, having the capability to absorb workers with low education, and can be conducting in small business activities, both traditional and modern. MSMEs are business on a small and medium scale, which are not a subsidiary or branch of any company. Thus, it can be defined that MSMEs are small businesses with income below 300 million and have workers under 20 people. Meanwhile, medium-sized businesses are businesses of income below 500 million that have the number of employees below 30 people (accurate.id, 2020 in Singawinata \& Saifulloh, 2021).

The portrait of Indonesian MSMEs shows that 81 percent of them are not familiar with the digital space in optimizing business opportunities. The opportunity for MSMEs to transform into digital onboard can contribute to MSME resilience in the midst of pandemic. Advances in technology and information as well as the increasingly sophisticated devices produced by the industry are rather like presenting the 'world in the palm of your hand'. This term is put forward by Thomas L. Friedman (2007) as 'the world is flat', meaning that the world is getting flatter and everyone can access anything from any source (Nasrullah, 2015).

The Human Resource Development Program is an opportunity and medium for the community to take an active role in selfdevelopment. Moreover, the information and communication technology sector is growing rapidly during this pandemic. One of the efforts to keep up with technological developments is to improve people's digital literacy skills. Digital literacy is the ability to utilize digital media as a source of knowledge and use it wisely in daily interactions. The productive use of digital technology as an individual empowerment practice is also a major focus in various digital literacy movements.

Data from various official institutions indicate that the Indonesian people in recent years have become quite open to new technologies, especially those related to digital media. This is supported by the fact that more than half of Internet users in Indonesia are from urban communities who are very familiar with various social media (We Are Social, Januari 2021).

According to data from Mampang Subdistrict, Kuningan Barat Urban Village area has experienced an increase in the number of MSMEs since the COVID-19 pandemic, namely 117 businesses. There are various types of business, such as food, beverage, food stalls, convenience stores and handicrafts. Around 70\% of these businesses are food businesses such as cakes, nasi uduk (rice cooked in coconut milk), snacks, and dry foods; while the rest are handicraft, basic food stalls, and herbal medicine. In Kuningan Barat Urban Village, there are 5 Community Units (RW) which are included in the category of Micro, Small and Medium Enterprises (MSMEs) fostered by the government, in this case the sub department of South Jakarta Maritime, Agriculture and Food Security (KPKP) (Tim Peneliti, 2020).

The Kuningan Barat Urban Village area is located in the center of Jakarta. This area is the most targeted area by business actors due to its easily accessible location and closeness to office buildings and other activities, such as schools and shopping mall. Currently, Kuningan Barat is filled with various businesses such as offices, housing/apartments, hotels, banks, restaurants, cafes, bars, salons, and other small businesses.

Kuningan Barat is experiencing rapid development due to its strategic location that attracts big business actors, but there 
are also many MSMEs that need attention and assistance. According to data from Mampang Sub-district, the most dominant business in Kuningan Barat Urban Village area is trade by $56.5 \%$, which consists of wholesale and retail trade. These trading businesses include food, beverages, snacks, cosmetics, clothing, hijab, accessories, motorcycle repair shops, mobile phone shops/counters selling credit/data, grocery stores and so on. The large number of trading businesses in this area can be seen from the number of micro businesses along the road that sell primary and secondary needs as well as other types of small businesses.

Majority of MSMEs actors in Kuningan Barat have no proper knowledge in using the digital to strengthen their economic activities, so that digital literacy is necessary. In general, MSME actors do have communication tools but have not used them optimally to support their activities or businesses.

Therefore, digitally literate MSME actors mean they can improve their capabilities and match the medium for information to be conveyed to the audience. In other words, digital literacy can also increase the ability of users to suit the medium with the information offered to the audience (Lanham, 1995). In a further study, this digital literacy process involves authentic multi-text, processed with various devices and code switching to understand the content of many users on a single subject (Chase, 2011) in (Sabrina, 2019).

The concept of digital literacy has gone through a long process. The term digital literacy by definition was originally used in the 1980s when computing technology began to be used to support everyday life (Widyastuti et al., 2016). The concept of digital literacy was first put forward by focusing on how to form an audience that was able to search, process, and use various information online (Gilster, 1997). The connection between digital literacy and information was one of the main focuses emphasized in various digital literacy programs. However, this was later criticized because literacy skills should not only focused on the relation with information, but should also cover a wider field. Digital literacy is required to be able to instill critical thinking skills and be sensitive to various existing sociocultural phenomena. Digital technology should not only seen as an instrument or tool, but also as part of the life of society at large where technology will always shape and be shaped by its users (Buckingham, 2015) in (Rahmawan et al., 2019).

The concept of digital literacy continues to transform from time to time (Potter, 2010). Initially, this concept was known as media literacy which advocated the importance of a critical attitude towards television. This concept continues to be echoed until the emergence of communication technology and internet. In the era of the birth of computers, the concept of media literacy was interpreted as the skills possessed by individuals to be able to operate computer devices (Buckingham, 2015) in (Sabrina, 2019). Slowly but surely this concept is transformed into information literacy when the internet is still being used and functions as a medium that provides broad access to information. Currently, the concept used is digital literacy in (Limily \& Aristi, 2019). Studies on digital literacy have been carried out by several experts including David Bawden, Gloria E. Jacobs, Sonia Livingstone, Guy Merchant, and also Ezter Hargittai (Mathar, 2014) in (Kusuma \& Sugandi, 2019).

Digital literacy is the knowledge and skills to use digital media, communication tools, or networks in finding, evaluating, using, creating information, and utilizing it in a healthy, wise, intelligent, careful, precise, and law-abiding manner in order to foster communication and interaction in daily life. 
In the beginning, literacy only refers to the ability to read and write texts as well as to interpret (UNESCO, 2005). However, now the concept of literacy continues to develop and is divided into several forms, one of which is digital literacy. In another sense, digital literacy is the knowledge and skills of users in utilizing digital media such as communication tools, internet networks, and others. User skills in digital literacy include the ability to find, work on, evaluate, use, create and utilize information in digital media wisely, intelligently, carefully, and precisely according to the use. Handling a variety of information, the ability to interpret messages, and communicate effectively with others are various skills covered in digital literacy. The process of creating, collaborating, communicating based on ethics, understanding when and how to use technology effectively are digital competencies needed today (Suherdi, 2021; Restianty, 2018, Delmia et al, 2019).

How to use digital media in term of communication tools, internet networks, content or messages, targets and creativity is certainly a distinctive knowledge for users, in this case, MSME actors.

There are several things in the use of digital media that people need to know so that they can apply digital literacy according to their needs. As Steve Wheeler (2012) in (Liansari \& Nuroh, 2018) stated that important elements of digital literacy relating the skills should be mastered in the use of information and communication technology are as follows: 1) Social Networking, which is the skill of using various social network services; 2) Transliteracy, the ability to use various digital platforms; 3) Maintaining Privacy, namely the ability to manage and maintain the privacy of digital data; 4) Managing Identity, which is the ability to apply the right identity on various digital platforms; 5) Creating Content, namely the ability to create appropriate content on various digital platforms; 6) Organizing and Sharing Content, which is the ability to organize and share content appropriately on various digital platforms; 7) Repurposing Content, namely the ability to use or combine the existing content to produce new, creative content; 8) Filtering and Selecting Content, which is the ability to filter and select proper content according to the needs; and 9) Self Broadcasting, which is the ability to share private content appropriately.

In this context, the development of MSMEs must be placed as an effort to increase the productivity of public sector. Holzer \& Callahan (1998 in Ismi 2015) suggest that the integration of quality management, human resource development, technology adaptation, strategic partnerships, and organizational performance measures will result in increased productivity of public sector when they synergized with capital, labor and energy.

The ability of individuals to be able to access information in the digital era is crucial, including for women. In relation to this research, women who drive MSMEs should have a high level of digital literacy so that MSMEs development can be carried out optimally.

Digital literacy according to Potter in (Widyastuti et al., 2016) is an individual's interest, attitude, and ability to use digital technology and communication tools to access, manage, integrate, analyze and evaluate information, create and build new knowledge, and communicate with other people to be able to participate effectively in the society. In Potter's conception, the effort to build a digitally literate society does not merely to introduce them with digital media, but also to synergize digital media with daily activities (including organizations) that lead to increased productivity.

This research is strengthened by the use of literature reviews from two similar previous studies. The first study was 
conducted by (Erika, 2019) with the aim of research to identify the affectivities of women's digital literacy in using digital media, particularly on social media. Subject of the research was the Indonesian Army's Wives Association (PERSIT) Squadron 31 PUSPENERBAD Semarang. The method used was a qualitative method to observe and sharpen information and analysis among resource findings. The results of research showed that the wives of army mostly used social media to get information accessed from their cellphones. Respondents used social media to exchange information, maintain friendships, buy and do marketing online, take vacations and get selfactualization. Socialization and reprimands were performing routinely during the association meetings. Digital literacy provided positive side and the women understood the negative sides as well for using digital media inappropriately that would impact not only the person concerned, but also his/her family and institution. In PERSIT organization, which still had strongly military hierarchy culture, reprimands from superiors had the effect of repenting for members who were proven to have misused digital media.

The similarity of this research with the first research lies in digital literacy as the concept of the study, research approach, and data collection method. While the difference lies in the object of research and research objectives that lead to different research results.

The second study was conducted by (Widyastuti et al., 2016) with the aim of identifying the reality of women's activities in using digital media. The research subjects were Micro, Small and Medium Enterprises (MSMEs) in the Special Region of Yogyakarta. The research method used was qualitative to review information as findings obtained from informants. The results of this second study indicated that women limit their access to information and communication technology. They used digital media to get information that supports their activities. These female respondents used mobile phones and personal computers to access the internet. Respondents used cell phones more often than personal computers. This research provided policy input that digital literacy played an important role in the continuation of women's activities. The process of adopting innovative technology increased the ability of women to advance MSME activities. In addition, internet access increased women's economic sustainability.

The similarity of this research with the second research lies in the concept and research subject, namely the MSME actors and the research approach used. Meanwhile the difference lies in the research objectives and the unit of analysis of digital media literacy, in which this study emphasizes the results of digital literacy in the form of respondents' understanding of using digital media.

\section{METHOD}

This research uses the Participatory Action Research (PAR) method. Basically, $\mathrm{PAR}$ is research that actively involves all relevant parties (stakeholders) in reviewing ongoing actions (with their own practice as a problem) in order to make changes and improvements for the better (Afandi et al, 2016).

Furthermore, it is said that PAR has three words that are always related to one another, namely participation, research and action. All research must be put into action. Likewise, research has its consequences. Everything changes as a result of research. The new situation caused by research may be different from the previous one.

According to Corey (1953), method of action research is a process in which social groups attempt to scientifically study their problems in order to direct, improve, and evaluate their decisions and actions. The 
PAR method was chosen because the research team realized the importance of active community involvement, in this case, MSME actors. The PAR method requires the research team to be directly involved with the community (MSMEs actors) with the aim of strengthening their capacity to make plans, take decisions and concrete actions to improve the conditions of local communities (Cavestro, 2003) in (Widyastuti et al., 2016).

Actions based on participatory research will hit the right target, namely resolving the problems and according to the needs. This activity will keep on going until a cycle of stages is built in the cycle model that has four stages, namely planning, action, observation, and reflection as the concept of (Kemmis et al., 2014). The results of evaluation and reflection on the first research are aimed at the target group who will be the focal point which will then become the material for researching the condition of research subject after the action. The application of model at focal point is carried out as a model testing action which will then be applied to target subjects in other areas.

Furthermore, the results obtained from previous research using the PAR method will be employed as the basis for building a digital media utilization model, in particular to optimize MSME productivity in terms of organizational management and digital-based business development, namely digital marketing. The emphasis on digitalbased management is carried out in the context of how technology, notably information technology, affects the communication work of organizational members. Information technology will improve the ability of managers to monitor team performance, expand access to information, and increase collaboration opportunities. In addition, information technology allows members of the organization to be connected to each other intensively so that work processes can be carried out more efficiently.

Meanwhile, digital marketing emphasized in this research is the promotion of MSMEs using digital media to reach consumers in a timely, personal, and relevant manner. The digital media in question focuses on new electronic media that are connected to the internet, while the applications mostly used are social media applications such as facebook, instagram, youtube, whatsapp business, and even the creation of a digital marketing website as a forum for promoting MSMEs online.

\section{DISCUSSION}

Micro, Small and Medium Enterprises (MSMEs) are one of the sectors that have a crucial role in the economy of Indonesia since they have great potential to drive economic activity and become the main source of income for most people. MSMEs can absorb workers with low education and run small business activities, both traditional and modern.

Mampang Prapatan Sub-district has 5 urban villages, and out of these urban villages there are a total of 414 microenterprises. The largest number of micro businesses is in Bangka Urban Village with a total of 90 businesses. The following is a table of the number of micro-enterprises in Mampang Prapatan Sub-district based on 2018 urban village data:

Table 1. Number of MSMEs in Mampang Prapatan Sub-district

\begin{tabular}{llc}
\hline No & Urban Village & $\begin{array}{c}\text { Number of } \\
\text { Businesses (Unit) }\end{array}$ \\
\hline 1 & Bangka & 90 \\
2 & Pela Mampang & 85 \\
3 & Tegal Parang & 80 \\
4 & Mampang Prapatan & 78 \\
5 & Kuningan Barat & 82 \\
& Total & 414 \\
\hline
\end{tabular}

Source: KPKP of Mampang Prapatan, 2018

Data from Mampang Sub-district shows that since the COVID-19 pandemic, Kuningan Barat Urban Village area has experienced an increase in the number of 
MSMEs up to 117 businesses. The types of business vary, such as food, beverages, stalls, convenience shop, and handicrafts. Around $70 \%$ of these businesses are food businesses such as cakes, nasi uduk (rice cooked with coconut milk), snacks and dry foods; while the rest are handicrafts, basic food stalls, and herbal medicine. There are 5 urban villages (RW) in Kuningan Barat Sub-district which are included in the category of Small and Micro Enterprises (UKM) fostered by the sub department of South Jakarta Maritime, Agriculture and Food Security (KPKP).

In general, MSMEs actors have means of communication and run mediocre businesses. They have not been able to market their products online because they do not master the use of digital media. Let alone the problem of Covid-19 pandemic that inhibits MSMEs actors to sell their products directly.

Based on the results of interviews, some MSMEs actors in Kuningan Barat Urban Village area revealed the problems faced during the crisis of COVID-19 pandemic, namely capital and the use of digital technology. Capital is the main factor to keep their businesses running smoothly. The availability of capital has an impact on income since it affects the number of products that can be sold. Capital is needed continuously for a business to be developed through the addition of tools, materials and services used in production to obtain sales outcomes. However, the use of digital technology for product marketing can also present obstacles when there are competitions and the increasing and complexity of market reach (Tim Peneliti, 2020).

Based on the three-months research, initial findings were obtained that became the basis for developing digital literacy programs, including ownership and the ability to access digital facilities, especially computers, as well as the ability to access and utilize social media and the use of digital platforms.

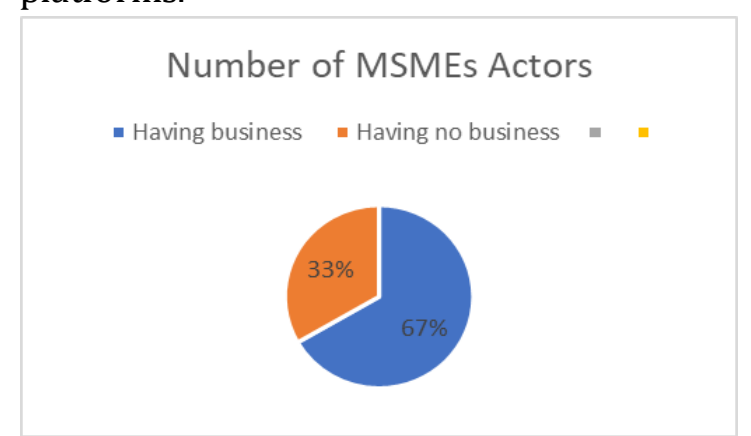

Figure 2. Number of Active MSMEs Actors

Data in figure 1 above shows that of the 117 MSMEs in Kuningan Barat, 96\% of them (74 people) already have a business, while $4 \%$ (37 people) do not have a business yet. Those who already have businesses run their businesses through word of mouth promotion, personal WhatsApp and text messages, and have not received regular assistance; while those who do not have a business own the means of communication but have not yet decided what type of business they should run to.

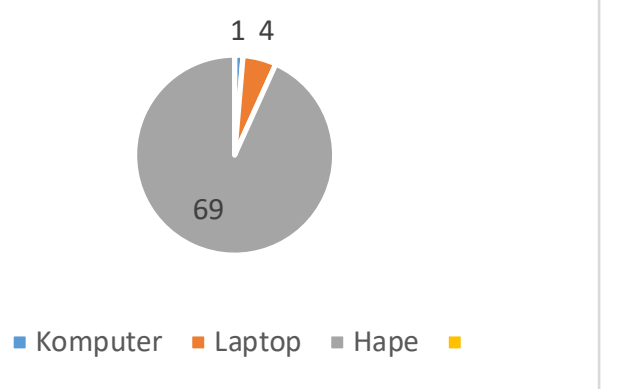

Figure 3. Devices to Access the Internet

In figure 3, MSME actors already have digital media facilities in the form of computers, laptops and cellphones but have not optimally utilized these devices for the purpose of marketing their products. The most widely used device is cell phones but they are still personal and have not yet maximized for business purposes. 


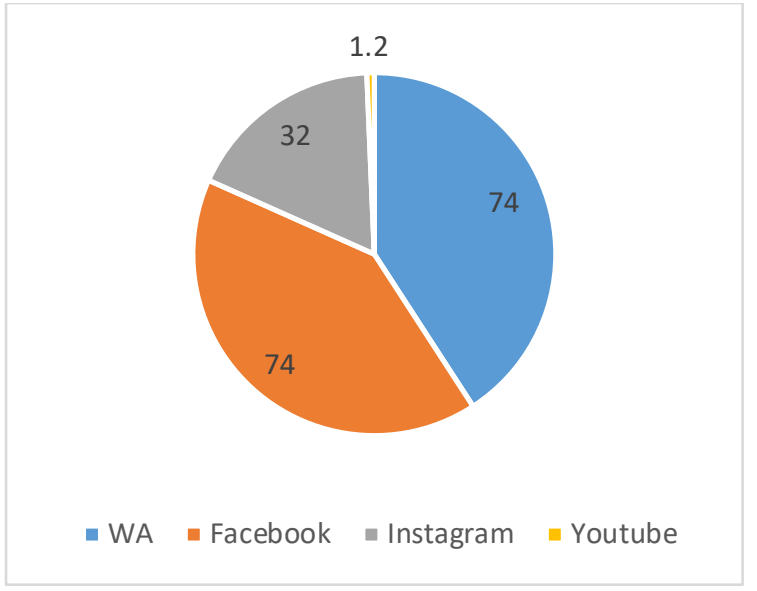

Figure 4. Frequently Opened Platforms

In figure 4, all MSMEs actors have personal WhatsApp for the sake of information and socialization among them; they also have Facebook, Instagram and Youtube to browse and buy various products. Some of the MSMEs actors have already used Facebook to sell their products even though it is not maximized due to the lack of focus and limitations in creating content and optimizing the platform.

From these data, the stages of digital literacy for MSMEs in the Kuningan Barat Urban Village are carried out according to their conditions and abilities as follows:

Social networking is the skill of using various social networking services. Researchers find that the most widely used social media are Facebook, Instagram and Whatsapp. Through socialization and training program, MSMEs actors learn to optimally use the social media they already had, for example Facebook by utilizing its existing facilities of Marketplace. Through this facility, MSME actors can market their products and exchange information with other users or marketers in market place. MSME actors also learn how to maximize the use of Instagram: put up good and interesting product photos, write an appealing caption photos, and of course, create attractive displays. Another social network mostly used by MSMEs is personal Whatsapp (WA). In the training, MSME actors are recommended and learn how to use WA Business which has more benefits for their business. Knowing the advantages of WA business and how to use it is an advance step in understanding digital media to run a business.

Transliteracy is defined as the ability to use various digital platforms. Prior to socialization and training, MSME actors had not been able to use digital platforms optimally. After the training, they understand the advantages and disadvantages of each digital platform. They learn how to use personal and business WA, also take advantage of Shopee, Tokopedia, and Lazada e-commerce by setting targets to market their products appropriately.

Maintaining Privacy is the ability to manage and maintain the privacy of digital data. Through socialization and training, MSME actors understand which data is personal and which data is general that can be shared publicly. They understand the improper use of data so that they can use data on digital platforms according to their needs and benefits.

Managing Identity is the ability to use the right identity on various digital platforms. After socialization and training, MSME actors can use their identity properly and in detail on digital platforms and social media which make it easier for others to see them clearly for the benefit of marketing the products. Names and locations and types of products are displayed properly so that they can be accessed by the public, hence buying and selling transactions can be carried out appropriately and continuously.

Creating Content is the ability to create valuable content across various digital platforms. Through socialization and training, MSMEs actors can create content about their products. Product names, product stories, attractive photo displays, price information, product advantages, product contents (for food), as well as an explanation of product manufacturing are 
details that must be shared by MSMEs actors so that they can be seen clearly by people who want to buy the product. The ability to create content is important for MSMEs actors to differentiate their products from similar products on digital platforms.

Organizing and Sharing Content is the ability to organize and share content appropriately on digital platforms. Through socialization and training, MSMEs actors learn to understand the nature and character of every platform so that they are able to organize and share content according to the target market and the intended buyer or consumer niche. MSMEs actors should know that each digital platform is unique and has a different market niche so that it is crucial to share appropriate content for different platform.

Repurposing Content is the ability to use or combine existing content to produce new, creative content. Through this socialization and training, researchers create simulations about the use and incorporation of existing content on the platform. MSME actors who have already made content are taught to create new content (creative writing), either in choosing appropriate and interesting fonts, colors, and product photos. Previous contents created by MSME actors were mostly unattractive to read and the photos lacked of lighting (did not look fancy), thus by repurposing these contents they look like new ones.

Filtering and Selecting Content is the ability to filter and select the right content according to your needs. Through socialization and training, MSME actors learn to filter and choose the right content according to their needs. This can be seen from the posts on WA Business, Facebook and Instagram where MSME actors are able to share product content with business partners who have similar businesses with them. They have also been able to filter out the right content for their business interests.

Self Broadcasting is the ability to share private content appropriately. Through socialization and training, MSME actors learn to share personal content with friends in WA groups, Facebook and Instagram according to the characteristics of each platform. They display photos on WA Business with the caption that invite viewers to buy their products and share them with other users. Likewise on Facebook, MSME actors have been able to share photos and write captions well and add names listed on their friendship. The same thing applies to Instagram, where MSME actors have been able to share good photos with relevant captions.

Action Research Participation (PAR) for digital marketing emphasized in this study is an effort to promote MSMEs through digital media to reach consumers in a timely, personal, and relevant manner. The digital media in question focuses on new electronic media that are connected to the internet, while the applications being used are mostly social media such as Facebook, Instagram, YouTube, WhatsApp business, and the creation of a website of digital marketing as a medium for promoting MSMEs online. 

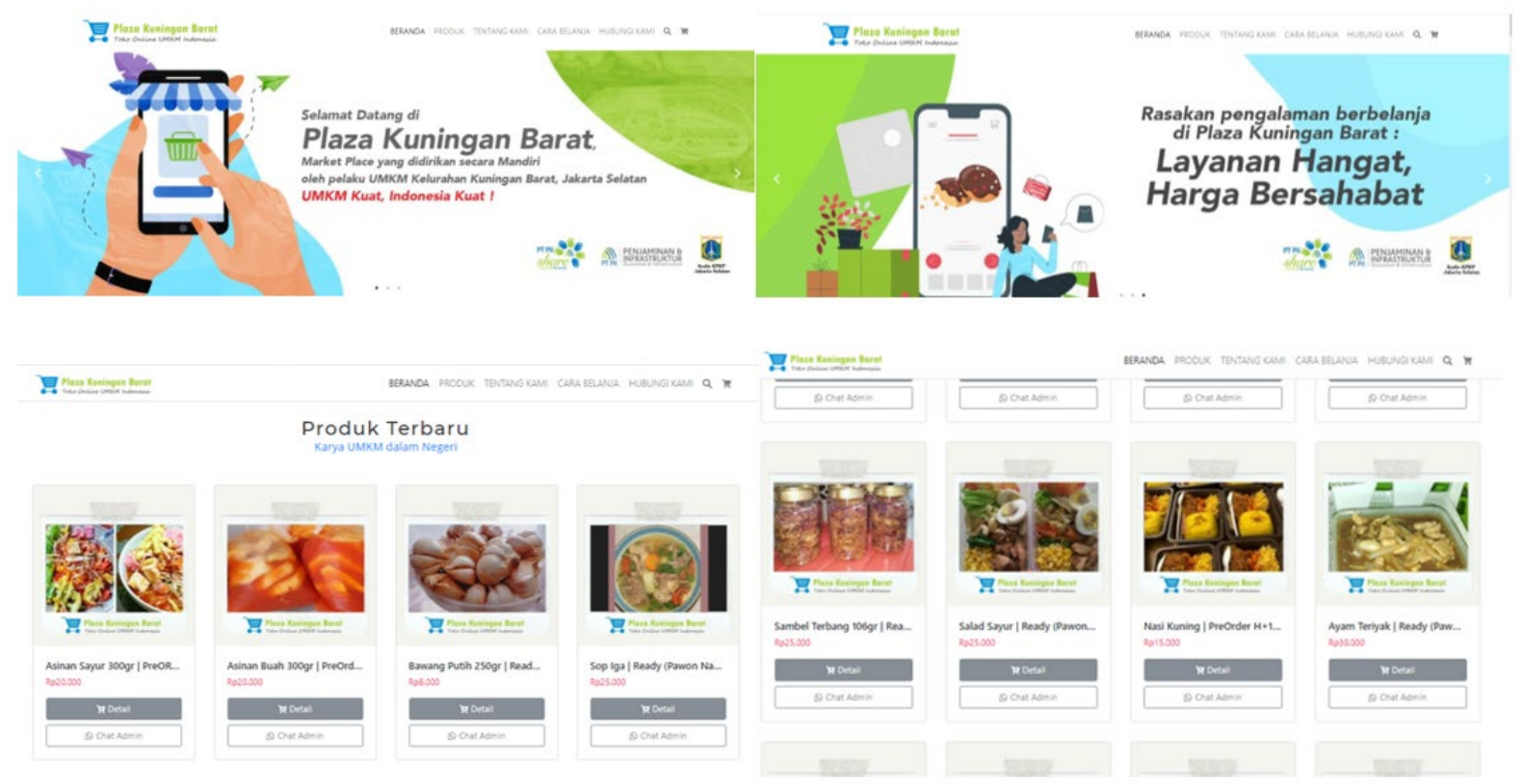

Figure 5. Website Display of Kuningan Barat MSMEs

(Source: www.plazakuninganbarat.com, 2021)

\section{CONCLUSION}

Through socialization and digital literacy training, MSMEs actors in Kuningan Barat, Jakarta Selatan (South Jakarta) can optimally use digital platforms. Proper socialization and training can improve knowledge and skills of MSME actors from being passive to active. MSMEs actors can also create catchy content accompanied by attractive photo displays about their businesses. Through Action Research Participation research, the processes carried out can be more effective with the results that can be seen, measured and evaluated. The use of digital media, both application and digital platform, is very helpful for MSME actors in increasing their skills and income by turning home-based products into products that are acceptable to the public due to attractive packaging and content. Thus, stakeholders of government, private sector and community need to collaborate to improve understanding and skills in using digital literacy so that UMKM actors can improve their standard of living by selling their products.

\section{REFERENCES}

Agus Afandi, dan Rekan. (2016). Modul Participatory Action Research (PAR): Untuk Pengorganisasian Masyarakat. Surabaya: LPPM UIN Sunan Ampel

Asosiasi Penyelenggara Jasa Internet Indonesia. (2020). Laporan Survei Internet APJII 2019 - 2020. Asosiasi Penyelenggara Jasa Internet Indonesia, 2020, 1-146. https://apjii.or.id/survei

Erika, D. (2019). Literasi Digital Perempuan Pada Organisasi Persatuan Istri Prajurit (PERSIT). Interaksi: Jurnal Ilmu Komunikasi, 8(2), 36. https://doi.org/10.14710/interaksi.8. 2.36-45

Kemmis, S., McTaggart, R., \& Rhonda, N. (2014). The Action Research Planner (Doing Critical Participatory Action Research). Singapore Springer. https://doi.org/10.1007/978-9814560-67-2

Kusuma, D. F., \& Sugandi, M. S. (2019). Strategi Pemanfaatan Instagram Sebagai Media Komunikasi Pemasaran Digital Yang Dilakukan Oleh Dino Donuts. Jurnal Manajemen Komunikasi, 3(1), 18-33. https://doi.org/10.24198/jmk.v3i1.1 2963 
Liansari, V., \& Nuroh, E. Z. (2018). Realitas Penerapan Literasi Digital bagi Mahasiswa FKIP Universitas Muhammadiyah Sidoarjo. Proceedings of the ICECRS, 1(3), 241-252. https://doi.org/10.21070/picecrs.v1i 3.1397

Limili, Putri; Aristi, N. (2019). Literasi Media dan Digital di Indonesia: Sebuah Tinjauan Sistematis. Jurnal Komunikatif, $\quad 8(2), \quad 205-222$. https://doi.org/10.33508/jk.v8i2.219 9

Nasrullah, R. (2015). Media Sosial Perspektif Komunikasi, Budaya dan Sosioteknologi. Simbiosis Rekatama Media.

Permadi, D. (2021). Konstan Menjaga Pertumbuhan Sektor Informasi dan Komunikasi.

https://kominfo.go.id/index.php/con tent/detail/3415/Kominfo+\%3A+Pen gguna+Intern

et+di+Indonesia+63+Juta+Orang/0/b erita_satker

Rahmawan, D., Mahameruaji, J. N., \& Anisa, R. (2019). Pengembangan Konten Positif Sebagai Bagian Dari Gerakan Literasi Digital. Jurnal Kajian Komunikasi, 7(1), 31.

https://doi.org/10.24198/jkk.v7i1.20 575
Restianty, A. (2018). Literasi Digital, Sebuah Tantangan Baru Dalam Literasi Media. Jurnal Gunahumas, 1(1), 72-87.

Sabrina, A. R. (2019). Literasi Digital Sebagai Upaya Preventif Menanggulangi Hoax. Communicare: Journal of Communication Studies, 5(2), 31. https://doi.org/10.37535/10100522 0183

Singawinata, I. P., \& Saifulloh, M. (2021). Membangun ekosistem digital UMKM di era pandemi COVID-19 melalui PT PII (Persero) di, Kuningan Barat, Jakarta. Jurnal Pustaka Dianmas, 1(1), 6-11.

https://journal.moestopo.ac.id/index. php/dianmas/article/view/1494

Social, W. A. (2021). digital-2021-the-latestinsights-into-the-state-of-digital. We Are Social.

Suherdi, D. (2021). Peran Literasi Digital di Masa Pandemi. Deli Serdang: Cattleya Darmaya Fortuna.

Widyastuti, D. A. R., Nuswantoro, R., \& Sidhi, T. A. P. (2016). Literasi Digital pada Perempuan Pelaku Usaha Produktif di Daerah Istimewa Yogyakarta. Jurnal ASPIKOM, 3(1), 1-15. https://doi.org/10.24329/aspikom.v $3 \mathrm{i} 1.95$ 